INTERNATIONAL HIGHER EDUCATION - NUMBER 66 WINTER 2012 Pages 32-33.

Student Participation in Higher Education Governance in Europe Manja Klemenčič

Manja Klemenčič is postdoctoral researcher at the Centre for Education Policy Studies at the University of Ljubljana, Slovenia. E-mail: manja.klemencic@gmail.com.

Student participation in higher education governance is considered one of the foundational values in European higher education. This policy is derived from the democratic model of higher education governance, which emerged in Europe after the student revolts in the 1960s, and stipulates that universities as public institutions ought to be governed democratically. Moreover, this factor implies the participation of all politically significant constituencies, including students. Such student participation is also linked to the notions of higher education as a public good and of students as custodians of public interest. Today, students as a collective body in some way represent a part of higher education governance, basically, in every European country.

\title{
EUROPEAN VARIATIONS
}

Among European countries, quite a variety exists: if national legislation specifies the composition of internal and external stakeholders in institutional governance arrangements or if institutions have the autonomous prerogative to decide on these issues. Typically, legislation tends to specify provisions on the roles, 
responsibilities, and composition of the central institutional governing bodies. Accordingly, student participation in academic senates tends to be the strongest across institutions and countries. Subinstitutional aspects are decided on the institutional level—and may or may not be regulated in the organization's bylaws. Thus, noticeable differences arise between countries and even institutions within the same systems. Based on legal provisions, student participation may be granted by purely consultative or decision-making bodies, and students may or may not enjoy full voting rights on all issues. In view of these differences between countries, representative student organizations have continued to argue a case for more participation—formal as well as actual.

\section{Student Participation AND the Bologna Process}

The European Students' Union, the European platform of national student representations, brought the issue of student participation onto the agenda of the Bologna process (see IHE no. 50). Although it is an intergovernmental initiative, the Bologna process adopted a participatory governance approach. Stakeholder organizations, including the European Students' Union, have been involved as consultative members in the governing structures. Student participation has been a salient issue for the union. The European ministers responsible for higher education have spoken in favor of both: student involvement in the policymaking of the emerging European Higher Education Area and student decision-making participation in European, national, and institutional levels. Such political affirmation was virtually unprecedented within European higher education. Still, the extent and degree of student participation as a policy objective was left rather ambiguous. Given the consensual nature of the Bologna 
process, such ambiguity indicates the policy that was "in offensive" against potential rejection by reluctant governments.

\section{IMPROVEMENT OF STUDENT PARTICIPATION IN GOVERNANCE?}

The European Higher Education Area's political endorsement of student participation has been used by national representative organizations to consolidate or strengthen their participation in the national policy processes. The effects vary, however, among the countries depending on the pre-existing models of student interest intermediation. In some parts of Europe, such as central and southeastern Europe, the political endorsement led to improved student participation in national-level higher education policymaking. The general tendency across Europe has involved student representatives in the Bologna-initiated policy processes, while to a lesser degree, if at all, at the institutional level. Now, governance reforms sweeping across Europe evince a changing trend of the student participatory model—an erosion of students' involvement of decision making on all vital policy and strategy. Along with other internal stakeholder representatives, student representatives are increasingly being eclipsed by the executive leadership, and their role is increasingly being transformed from decision making to an advisory factor.

\section{University Governance Reforms and New Public Management}

With the increasing pressure to modernize European higher education, universities have been granted more institutional autonomy. In general, European universities have created managerial infrastructures parallel to academic ones. This tendency shifts in decision making from collegiate 
governing bodies, in which students are formally represented, to managerial bodies where they are represented less or not at all. In case of Portugal, for example, the new provisions stipulate student participation in the Conselho Geral, but the minimal share of student representatives is not specified. The arguments given for the change covered disturbance of student representatives (e.g., fights over tuition fees) and the effectiveness of decision making. Concomitantly, the relative political weight of student representatives in university boards has declined. In sum, strong executive leadership has been viewed as a new ideal for supplanting the representative democracy model, discussed above.

\section{StUdents As CLIENTS}

Given the global financial crisis across Europe, the overall trend creates the burden of financing public higher education shifting from governments to institutions and their students. The creation or substantial increase of tuition fees in some countries has significant impacts on student-university relations. Tuition-paying students-conceived as clients, rather than partners-fit well into the emerging ideal of the modern "corporate" university. Identifying students as clients does not preclude student participation in institutional governance, but it fundamentally transforms it. The contemporary institutional preference for student participation clearly constitutes an advisory rather than a decision-

making function. Students are invited to contribute in institutional qualityassurance procedures in terms of improving services and overall institutional performance. 


\section{EUROPEAN VARIATIONS}

The trend in institutional governance across Europe is clearly seen as weakening formal student participation and strengthening informal student participation. The extent of such developments depends on the specific national model of student representation and how formalized and strong the channels of student involvement in higher education governance are on various levels. In statist countries with weak student representation, the conception of students as consumers may well be overriding the traditional idea of students as partners. Both conceptions are attempted to be combined in corporatist countries, such as the Nordic states, with mature and highly developed student organizations and with strong channels of influence to higher education governance, on all levels. 